\title{
Skills and competences of audio describers in Spain ${ }^{1}$
}

\author{
Nuria Mendoza \\ Universitat Autònoma de Barcelona and Universidad Nebrija, Spain \\ Nuria.mendozaD@e-campus.uab.cat \\ https://orcid.org/0000-0001-6044-8702 \\ Anna Matamala \\ Universitat Autònoma de Barcelona, Spain \\ Anna.Matamala@uab.cat \\ https://orcid.org/0000-0002-1607-9011
}

\begin{abstract}
This article describes the skills and competences that professional audio describers should acquire, based on the results of a questionnaire and on interviews with lecturers of AD courses in the context of Spanish MAs. First, the input provided by audio describers and end-users for a questionnaire conducted under ADLAB PRO, an Erasmus+ project funded by the European Commission, is discussed; it focuses on data from Spanish participants. Secondly, the skills and competences identified through the questionnaire are compared to those included in specific courses on audio description within MA programmes offered at Spanish universities. The article begins with a brief discussion of terminology and ends with a discussion on how the results of our research could have an impact on training proposals for AD.
\end{abstract}

Keywords: audio description, didactics, media accessibility, ADLAB PRO

\section{Introduction}

Defining the skills and competences of future professionals is fundamental to guaranteeing adequate training and future employability. This article focuses on researching the skills and competences of the audio describer in Spain.

The study of audio description (AD) didactics is still in its infancy. Mendoza and Matamala (2019) offer an overview of the main contributions in this regard (Álvarez de Morales Mercado, 2017; Cambeiro Andrade \& Quereda Herrera, 2007; Martínez Sierra, 2012; Marzà Ibáñez, 2010; Matamala, 2006; Matamala \& Orero, 2007; Remael \& Vercauteren, 2007, Reyes, 2007; Snyder 2008, 2014) and highlight Díaz Cintas's (2006) input. Díaz Cintas (2006) identified the competences that both subtitlers and audio describers should acquire, and categorized them as follows: (i) linguistic; (ii) content-related or thematic; (iii) technical and applied, and (iv) personal and general. Ten years after the creation of these categories, these competences 
Mendoza, N., \& Matamala, A. (2019). Skills and competences of audio describers in Spain. Linguistica Antverpiensia, New Series: Themes in Translation Studies, 18, 144-165.

are still relevant and necessary in the light of the professional practice of AD (Sanz-Moreno, 2018).

Various MA programmes in which $A D$ is taught have been identified at a number of Spanish universities (see section 3.2). A prerequisite of launching these programmes has been to define a series of competences and learning outcomes that professionals are to acquire.

Two methodological tools have been used in our study: the first is a European-wide questionnaire developed as part of the European project called ADLAB PRO (Audio description: A laboratory for the development of a new professional profile); the second is a series of interviews with five AD lecturers in Spanish MA programmes. ADLAB PRO is a European project which aims to define the skills and competences of the professional audio describer and to generate training materials ( $A D L A B$ PRO, n.d.). In a first stage, the project gathered information on $A D$ practices and training by means of two questionnaires. The results of the first have been analysed by Mendoza and Matamala (2019), mapping AD teaching practices in Spain. Focusing on the skills of audio describers in Spain, the present article analyses the data of the second questionnaire and the input of the abovementioned interviews in order to compare the skills included in the questionnaire with those of students in Spanish MAs where audio description is taught.

The present article begins with a short introduction to key concepts in the European Higher Education Area (section 2) and defines the methodological approach (section 3). Section 4 reports on the results of the questionnaire and section 5 presents the results of the interviews. Conclusions and proposals for future research are found in section 6 .

\section{Defining skills and competences}

Skills, competences and related terms are defined and used differently (UNESCO-IBE, n.d.; Kennedy, 2007; Sarzoza Herrera, 2007). The European Qualifications Framework (EQF), which joins the qualifications of different EU members together, differentiates between: knowledge, which is described as "theoretical and/or factual"; skills, which are described as "cognitive (involving the use of logical, intuitive and creative thinking) and practical (involving manual dexterity and the use of methods, materials, tools and instruments)"; and competences, described "in terms of responsibility and autonomy" (European Commission, n.d., p. 2). The EQF shares the definition of competence with the European Skills/Competences, Qualifications and Occupations (ESCO), a European multilingual classification, as well as with the European Masters in Translation (EMT), a partnership project of the European Commission and a number of European universities. According to the EQF, ESCO and the EMT, competence is "the proven ability to use knowledge, skills and personal, social and/or methodological abilities, in work or study situations and in professional and personal development" (European Commission, 2017, p. 3). Within the EMT framework, knowledge is defined as "the outcome of the assimilation of information through learning", whereas skills mean "the ability to apply knowledge and use know-how to complete tasks and solve problems" (European Commission, 2017, p. 3). Despite differences between the three definitions, a common general collocation in the educational field found, for instance, in ESCO is "skills and competences". 
Mendoza, N., \& Matamala, A. (2019). Skills and competences of audio describers in Spain. Linguistica Antverpiensia, New Series: Themes in Translation Studies, 18, 144-165.

The creation of the European Credit Transfer System (ECTS) marked a new methodological model in higher education. ECTS are aimed at adding transparency to studies and courses (European Commission, 2015), because they are based on explicit learning achievements and course workload and allow students to transfer their ECTS between universities and countries. Besides, ECTS "encourages the paradigm shift from a teacher-centred to a learner-centred approach, which is, under the terms of Student-Centred Learning $(\mathrm{SCL})$, recognized as an underlying principle of the EHEA" (European Commission, 2015, p. 14).

The reformulation of the higher-education learning system also brought the concept of learning outcomes to the surface (Agencia Nacional de Evaluación de la Calidad y Acreditación, 2013). Although the idea of expecting results from students was not new, it became more holistic. Learning outcomes would thus be defined as "statements of what a learner is expected to know, understand and/or be able to demonstrate on completion of a learning process" (European Commission, 2015, p. 22). The concept of learning outcome was prioritized over that of learning objective, as it was considered to bring transparency to education and qualifications. The former is linked to the trainees' performance whereas the latter is more related to the teachers' intentions and does not necessarily lead to the achievement of learning outcomes.

Although in English the collocation "skills and competences" is widely used, in Spain, the focus of our research, the term "competencias" ("competences") is generally found in isolation, without "habilidades" ("skills"). When universities submit a new degree proposal for approval, there is a specific section in which they have to provide a list of competences, which are further specified in terms of learning outcomes for each course. In this article, we have decided to use the standard collocation "skills and competences" in the title. However, in the following sections, for the sake of brevity, the term "skills" is used with a wider meaning, following the terminology used in the ADLAB PRO questionnaire.

\section{Methodological aspects}

This article is based on a questionnaire and on interviews. The methodological aspects of these two are described next.

\subsection{The questionnaire}

The questionnaire ${ }^{2}$ was developed within ADLAB PRO through a collaborative process among partners with the goal of identifying the skills that audio describers need to acquire. It included four sections and three different categories (professional audio describers, end-users and service providers). The first section was addressed to all the respondents and included an introduction to the questionnaire, the terms of participation, instructions and a set of demographic questions. The three remaining sections were designed for the three target profiles, as follows (ADLAB PRO, 2017):

- Audio describers were asked about their professional activity, the status of $A D$ and their professional circle, and about skills and competences.

- End-users were asked about their experience as users, their perspective on the work of audio describers and about their satisfaction with regarding AD services. 
Mendoza, N., \& Matamala, A. (2019). Skills and competences of audio describers in Spain. Linguistica Antverpiensia, New Series: Themes in Translation Studies, 18, 144-165.

- Service providers were asked about their professional activity and about the skills and competences of audio describers.

Originally, the questionnaire was developed in English but then it was translated into all the partner languages (Italian, Polish, Spanish, Slovene and Dutch). It was made up of closed questions, giving the respondents the opportunity to add remarks. It was distributed online, through the platform Web Survey Creator, in an accessible format. Finally, it complied all due ethical and consent aspects.

Although the data gathered from the questionnaire addressed practices in a number of European countries, our analysis was based only on the data concerning practices in Spain. Additionally, respondent profiles with fewer than ten replies were discarded, as was the case with service providers (only two replies).

Taking the above into account, a total of 23 questionnaires were analysed, 11 corresponding to audio describers and 12 to end-users. Audio describers (36.36\% male, 63.63\% female) mostly hold an MA/MS (72.72\%). Age range was varied, $(27.27 \%=20-30,36.36 \%=31-40$, $18.18 \%=41-50,18.18 \%=61-70)$. The replies were also divergent when it comes to how long they have been working as audio describers $(<1$ year $=18.18 \%, 1-5$ years $=45.45 \%, 6-10$ years $=9.09 \%, 11-15$ years $=9.09 \%$ and $>20$ years $=18.18 \%)$. The amount of AD they have produced is generally vast $(>300$ hours $=54.54 \%,<50$ hours $=27.27 \%, 51-150=0 \%, 151-300$ $=9.09 \%$, and "other" $=9.09 \%$ ). Sixty per cent of the audio describers with 1-5 years of working experience have a production of $>300$ hours, closely followed by $20 \%$ with 151-300 hours of production and $20 \%$ with less than 50 hours.

This indicates that Spanish audio describers who have been working in $A D$ for a moderate number of years have a great deal of practical knowledge of $A D$. Besides, the correlation of those audio describers with most years of practice corresponds to their AD production, meaning that $100 \%$ of audio describers with $<1$ year of experience have $<50$ hours of production to their name. Fifty per cent of those with $>20$ years' working experience have a production of $>300$ hours. Unfortunately, the remaining $50 \%$ chose "other", with no further comments. Finally, the audio describer with 5-10 years' working experience has already achieved $>300$ hours of production.

Twelve questionnaires were completed by end-users ( $83 \%$ male, $17 \%$ female). There was a variation in their education $(25 \%=\mathrm{MA} / \mathrm{MS}, 25 \%=$ secondary school, $16.66 \%=$ vocational school and $8.33 \%$, each of these: PhD, BA/BS, primary school and "other") and age (20-30 years old $=16.66 \%, 31-40=16.66 \%, 41-50=25 \%, 51-60=33.33 \%$ and $61-70=8.33 \%) .67 \%$ were blind and $33 \%$ were partially blind.

\subsection{The interviews}

The overall aim of the interviews was to gather information about current $A D$ training practices in Spanish MAs. A specific aim was to identify the specific skills offered by such AD courses and to compare them to those previously analysed in the questionnaire. To that end, 36 different skills, the same as those in the questionnaires, divided into various categories 
Mendoza, N., \& Matamala, A. (2019). Skills and competences of audio describers in Spain. Linguistica Antverpiensia, New Series: Themes in Translation Studies, 18, 144-165.

(soft, textual/linguistic, technical, theoretical), were presented to the lecturers in the semistructured interviews that were planned.

The criteria for selecting the $A D$ courses were the following: the course should be taught in an official Spanish MA programme active in 2018-2019, it should have at least two ECTS and detailed information should be publicly available.

The first step was to identify the MAs in which AD could potentially be taught, such as MAs in Translation or Accessibility. A search was performed on the Spanish Registry of Universities, Centres and Titles (RUCT) (Ministerio de Educación, Cultura y Deporte, n.d.). Filters were applied in order to obtain a list of MA programmes containing the keywords "Translation", "Audiovisual Translation" or "Accessibility" in their titles. A final list of 60 was obtained.

The second step consisted of identifying whether or not those MA programmes included AD training. The curriculum of each MA title was checked on the web pages. The final list is found in Table 1. The first column indicates the course title. The second indicates the number of ECTS assigned to $A D$ training: " $3 / 6$ " means that $A D$ training corresponds to three ECTS in a course with a total of six ECTS, while "6/6" means that all six ECTS are on AD.

Table 1: AD courses in the official Spanish MAs

\begin{tabular}{|l|l|l|l|}
\hline Name of course & AD ECTS & Programme & University \\
\hline $\begin{array}{l}\text { Translation and accessibility } \\
\text { for the hearing and visually } \\
\text { impaired }\end{array}$ & $3 / 6$ & $\begin{array}{l}\text { MA in Audiovisual } \\
\text { Translation and } \\
\text { Localization }\end{array}$ & $\begin{array}{l}\text { Universidad Autónoma de } \\
\text { Madrid/Universidad } \\
\text { Complutense }\end{array}$ \\
\hline $\begin{array}{l}\text { Audiovisual translation and } \\
\text { accessibility }\end{array}$ & $6 / 6$ & $\begin{array}{l}\text { MA in Professional } \\
\text { Translation }\end{array}$ & Universidad de Granada \\
\hline $\begin{array}{l}\text { AD for the blind and the } \\
\text { visually impaired }\end{array}$ & $3 / 3$ & $\begin{array}{l}\text { MA in Specialized } \\
\text { Translation }\end{array}$ & $\begin{array}{l}\text { Universitat de Vic- } \\
\text { Universitat Central de } \\
\text { Catalunya/Universidad San } \\
\text { Jorge }\end{array}$ \\
\hline $\begin{array}{l}\text { AD and subtitling for the } \\
\text { deaf and hard of hearing }\end{array}$ & $4.5 / 9$ & $\begin{array}{l}\text { MA in Audiovisual } \\
\text { Translation }\end{array}$ & $\begin{array}{l}\text { Universitat Autònoma de } \\
\text { Barcelona }\end{array}$ \\
\hline $\begin{array}{l}\text { Audiovisual translation and } \\
\text { accessibility }\end{array}$ & $2.5 / 5$ & $\begin{array}{l}\text { MA in Creative and } \\
\text { Humanistic } \\
\text { Translation }\end{array}$ & Universitat de València \\
\hline
\end{tabular}

The third step was to identify the lecturers for the interview process. The main criterion for selection was that they should have taught the course during at least one of the past three academic years. A final list of candidates was obtained and they were contacted via email.

An interview protocol was created with three main blocks: (a) educational and professional background; (b) teaching methodology, and (c) assessment of AD training. The lecturers were asked 24 questions, out of which 22 were open questions and two were tables with different 
Mendoza, N., \& Matamala, A. (2019). Skills and competences of audio describers in Spain. Linguistica Antverpiensia, New Series: Themes in Translation Studies, 18, 144-165.

statements the respondents had to rate. The abovementioned protocol was piloted with three informants and minor adjustments were made. Ethical clearance was obtained from UAB's ethical committee. The data related to block (a) and to skills, found in block (b), are reported here.

The interviews with five lecturers had an average duration of 87 minutes and took place in April-May 2019. The participants were informed about the project and signed consent forms. The interviews were performed online and were recorded in audio format. Data were then manually transcribed and personal data were anonymized.

Sixty per cent of the interviewees are undergraduates in Philological Studies and $40 \%$ in Translation and Interpretation Studies. Sixty per cent have MAs in Audiovisual Translation, $20 \%$ in Literary Translation and $20 \%$ have no MA. The respondents who did not study specialized courses in AVT started to approach the field either through conferences and seminars or by getting involved in Translation and AVT research groups. Finally, $80 \%$ have PhDs and $20 \%$ are currently PhD candidates. ${ }^{3}$ They have considerable AD teaching experience $(12,11,11,8$ and 2 years) and $40 \%$ are professional audio describers (8-10+ years' experience).

2018-2019 was the last year of AD courses taught in $80 \%$ of cases (20\% for $2017-2018$ ). Sixty per cent of the AD courses are taught face-to-face; $20 \%$ online and $20 \%$ either online or faceto-face. Sixty per cent of the AD training is made up of independent courses with more complex structures, as modules in which SDH is also taught. The workload of the AD courses ranges from 2.5-6 ECTS.

\section{Questionnaire results: skills of the Spanish audio describers}

ADLAB PRO questionnaire respondents were presented with a list of skills and had to rate them according to their importance. A five-point Likert scale was used (1 of no importance, 2 of minor importance, 3 neither important nor unimportant, 4 important, 5 extremely important). The taxonomy proposed by ADLAB PRO, inspired by Díaz Cintas (2006, pp. 51-57), included:

- Soft skills: personal and generic aspects.

- Technical skills: knowledge, ability and willingness to learn and manage general and specific AD software and technologies.

- Textual/linguistic skills: knowledge of language, creativity and linguistic sensitivity, among other aspects.

- Theoretical knowledge: knowledge in relation to accessibility in general and AD in particular, to cinematographic language and the semiotics of the image, and to the theory and practice of AD.

In addition, professional audio describers were asked about the most difficult aspects of the AD process on a five-point scale (1 extremely difficult, 2 difficult, 3 neither easy nor difficult, 4 easy, 5 very easy). These aspects included items found in the questionnaire under soft, technical and textual/linguistic skills. Finally, they were asked about the tasks they usually perform. 
Mendoza, N., \& Matamala, A. (2019). Skills and competences of audio describers in Spain. Linguistica Antverpiensia, New Series: Themes in Translation Studies, 18, 144-165.

End-users were asked about their level of satisfaction with the quantity and quality of ADs in Spain (very satisfied/satisfied/neither satisfied nor dissatisfied/dissatisfied/very dissatisfied), and about the aspects they appreciate and dislike most in an AD. In both cases a preestablished list of possible responses was presented.

\subsection{Audio describers: skills importance}

Tables 2 and 3 present a list of skills in order of importance, according to audio describers. Out of the first six items, five are textual/linguistic (Table 2). The items considered by audio describers as "extremely important" are: select significant visual information, which will allow the translation of visual stimuli into words, and possess an excellent command of their mother tongue; use a type of language suited to the product, express meaning succinctly and avoid ambiguous language are "important". "Target group", which refers to the knowledge an audio describer should have about the characteristics of end-users, especially about persons with sight loss, is the only non-textual/linguistic item in the uppermost part of the list.

Table 2: Skills assessed above 4

\begin{tabular}{|l|l|l|}
\hline Skill & Mean & Type \\
\hline Select significant visual information & 5 & Textual/linguistic \\
\hline Possess an excellent command of mother tongue & 5 & Textual/linguistic \\
\hline Use language that is suited to the product & 4.9 & Textual/linguistic \\
\hline Express meaning succinctly & 4.9 & Textual/linguistic \\
\hline Use non-ambiguous language & 4.81 & Textual/linguistic \\
\hline Target group & 4.81 & Theoretical knowledge \\
\hline Use language that is suited to the audience & 4.72 & Textual/linguistic \\
\hline Be assertive and fight for the quality of AD provision & 4.72 & Soft \\
\hline AD scriptwriting and textual editing & 4.72 & Technical \\
\hline $\begin{array}{l}\text { Provide the listener with a way of "seeing" what is being } \\
\text { described }\end{array}$ & 4.54 & Textual/linguistic \\
\hline Organize work efficiently & 4.54 & Soft \\
\hline Language and linguistics & 4.54 & Theoretical knowledge \\
\hline $\begin{array}{l}\text { Actively seek, evaluate and, if appropriate, incorporate } \\
\text { feedback }\end{array}$ & 4.54 & Soft \\
\hline World knowledge & 4.36 & Theoretical knowledge \\
\hline
\end{tabular}


Mendoza, N., \& Matamala, A. (2019). Skills and competences of audio describers in Spain. Linguistica Antverpiensia, New Series: Themes in Translation Studies, 18, 144-165.

\begin{tabular}{|l|l|l|}
\hline AD principles, guidelines, standards & 4.36 & Theoretical knowledge \\
\hline $\begin{array}{l}\text { Provide the listener with a way of “understanding" what is } \\
\text { being described }\end{array}$ & 4.27 & Textual/linguistic \\
\hline Media accessibility & 4.27 & Theoretical knowledge \\
\hline Have good communicative and interpersonal skills & 4.27 & Soft \\
\hline Work in a team with blind patrons & 4.18 & Soft \\
\hline Solve problems & 4.18 & Soft \\
\hline Use language that sparks the imagination & 4.09 & Textual/linguistic \\
\hline Scriptwriting & 4.09 & Theoretical knowledge \\
\hline Know when to call for expert help & 4.09 & Soft \\
\hline Use of AD software & 4 & Technical \\
\hline Technology of AD provision & 4 & Technical \\
\hline Audiovisual texts and multimodality & 4 & Theoretical knowledge \\
\hline
\end{tabular}

The typology of the six items considered the least important (Table 3 ) is varied: to improvise, to write quickly to a deadline, to compile an audio introduction, to know about translation studies and AVT as well as about AD history, status or applicable scenarios, and AD recording. In any case, none of the items are assessed below 2.45 ("of minor importance").

Table 3: Skills assessed between 1 and 3.99

\begin{tabular}{|l|l|l|}
\hline Skill & Mean & Type \\
\hline Cope with time pressure & 3.9 & Soft \\
\hline Mixing AD with original sound & 3.54 & Technical \\
\hline AD voicing & 3.54 & Technical \\
\hline Work in a team with colleagues & 3.45 & Soft \\
\hline AD recording & 3.45 & Technical \\
\hline AD history, status, applicable scenarios & 3.45 & Theoretical knowledge \\
\hline Translation Studies and AVT & 3.27 & Theoretical knowledge \\
\hline Compile an audio introduction & 3.27 & Textual/linguistic \\
\hline
\end{tabular}


Mendoza, N., \& Matamala, A. (2019). Skills and competences of audio describers in Spain. Linguistica Antverpiensia, New Series: Themes in Translation Studies, 18, 144-165.

\begin{tabular}{|l|l|l|}
\hline Write quickly to a deadline & 2.45 & Soft \\
\hline Improvise & 2.45 & Soft \\
\hline
\end{tabular}

Disaggregated data provide interesting insights. Regarding soft skills, audio describers consider that being assertive and fighting for the quality of AD provision is "important". To actively seek, evaluate and, if appropriate, incorporate feedback, to organize work efficiently, to have good communicative and interpersonal skills and to know when to call for expert help are also considered "important". For them it is also "important" to solve problems and to work in a team with blind patrons. Regarding the most important theoretical aspects, the participants select knowledge of target groups, language and linguistics, the world, and AD principles, guidelines and standards. Regarding technical skills, the participants give a 4.72 score to $A D$ scriptwriting and textual editing (in contrast to the 4.09 given to general knowledge of scriptwriting). This shows that more importance is attached to practice than to theory: scriptwriting in general refers to a theoretical skill in which audio describers acquire knowledge about how a film is built, whereas AD scriptwriting and textual editing refers to the actual ability of writing an AD script.

\subsection{Audio describers: skills' difficulty}

In addition, audio describers were asked to rate the same skills from a different perspective according to their difficulty. The specific question was: "What are the most difficult aspects you find when you audio describe?". The results show that all items were categorized either as "2 difficult" (43\%) or "3 neither easy nor difficult" (57\%). Out of the 12 items considered "difficult", 41.66\% are textual/linguistic. The four most difficult items (Table 4) are also textual/linguistic. However, none of them coincide with the most valued textual/linguistic skills previously identified (Table 2).

The most "difficult" soft skills were considered to be improvising, coping with time pressure and writing quickly to a deadline (Table 4), but they were also viewed as the two least important of all the skills (Table 3 ).

Table 4: Skills assessed between 1 and 2.99

\begin{tabular}{|l|l|l|}
\hline Skill & Mean & Type \\
\hline Choosing the most appropriate wording & 2.64 & Textual/linguistic \\
\hline $\begin{array}{l}\text { Providing the listener with a way of "understanding" what } \\
\text { is described }\end{array}$ & 2.73 & Textual/linguistic \\
\hline $\begin{array}{l}\text { Providing the listener with a way of "seeing" what is } \\
\text { described }\end{array}$ & 2.73 & Textual/linguistic \\
\hline Using language that sparks the imagination & 2.73 & Textual/linguistic \\
\hline Improvise & 2.73 & Soft \\
\hline
\end{tabular}


Mendoza, N., \& Matamala, A. (2019). Skills and competences of audio describers in Spain. Linguistica Antverpiensia, New Series: Themes in Translation Studies, 18, 144-165.

\begin{tabular}{|l|l|l|}
\hline Coping with time pressure & 2.73 & Soft \\
\hline Working in a team with blind patrons & 2.82 & Soft \\
\hline Writing quickly to a deadline & 2.82 & Soft \\
\hline Selecting significant visual information & 2.91 & Textual/linguistic \\
\hline Solving problems & 2.91 & Soft \\
\hline AD voicing & 2.91 & Technical \\
\hline Mixing AD with original sound & 2.91 & Technical \\
\hline
\end{tabular}

Table 5: Skills assessed between 3 and 5

\begin{tabular}{|l|l|l|}
\hline Skill & Mean & Type \\
\hline AD recording & 3 & Technical \\
\hline Using non-ambiguous language & 3 & Textual/linguistic \\
\hline Using language that is suited to the audience & 3.09 & Textual/linguistic \\
\hline Compiling an audio introduction & 3.09 & Textual/linguistic \\
\hline Expressing meaning succinctly & 3.09 & Textual/linguistic \\
\hline Being assertive and fighting for the quality of AD provision & 3.09 & Soft \\
\hline $\begin{array}{l}\text { Communicating and cooperating with others (peers and } \\
\text { blind persons) }\end{array}$ & 3.09 & Soft \\
\hline Using language that is suited to the product & 3.27 & Textual/linguistic \\
\hline Working in a team with colleagues & 3.36 & Soft \\
\hline AD scriptwriting and textual editing & 3.36 & Textual/linguistic \\
\hline Possessing excellent command of mother tongue & 3.45 & Textual/linguistic \\
\hline $\begin{array}{l}\text { Actively seeking, evaluating and, if appropriate, } \\
\text { incorporating feedback }\end{array}$ & 3.45 & Soft \\
\hline Using AD software & 3.54 & Technical \\
\hline Organizing work efficiently & 3.64 & Sechnical \\
\hline Using technology of AD provision & 3.45 & Soft \\
\hline Knowing when to call for expert help & 3.18 & Soft \\
\hline
\end{tabular}


Mendoza, N., \& Matamala, A. (2019). Skills and competences of audio describers in Spain. Linguistica Antverpiensia, New Series: Themes in Translation Studies, 18, 144-165.

\subsection{Audio describers: production stages}

Spanish audio describers were asked about the "stages" (as formulated in the original ADLAB PRO questionnaire) in which they are involved. The instructions were: "Which of the following stages of the production process do you have experience with?". One hundred per cent claim "to write and revise scripts" (Table 6), in line with European data (ADLAB PRO, 2017, p. 44), which confirms the need for audio describers to be trained in this area. AD voicing (63.63\%) and quality control tasks (45.45\%) follow. Only $18.18 \%$ assist in recording the AD with voice talents. None of the Spanish respondents translate AD scripts or use machine translation.

If we overlay this data with the list of skills (Table 2 and Table 3 ), the fact that $100 \%$ claim to write and revise scripts (Table 6) is consistent with the importance audio describers attach to textual/linguistic aspects. This scenario, in which voicing is performed by approximately $60 \%$ of respondents, can also explain why voicing was "neither important nor unimportant" (Table 3). Moreover, AD professionals in Spain are trained in scriptwriting-related aspects, which they perceive as very important, whereas the training of $A D$ voicing is scarce. Taking into account that voice talents usually narrate ADs in recorded content, this could indicate the reason for voicing being perceived as less important. Most of the participants are not involved in mixing the AD with the original soundtrack, which may be the reason why they consider it as "neither important nor unimportant" (Table 3).

Table 6: Most practised AD production stages

\begin{tabular}{|l|l|}
\hline Production stages & $\%$ \\
\hline Writing and/or revising the AD script & $100 \%$ \\
\hline Translating AD scripts & $0 \%$ \\
\hline Using machine translation with post-editing & $0 \%$ \\
\hline Voicing the AD & $63.63 \%$ \\
\hline Assisting in recording the AD with voice talents & $18.18 \%$ \\
\hline Mixing the AD with the original soundtrack & $27.27 \%$ \\
\hline $\begin{array}{l}\text { Quality control of the final product (e.g., checking the script or recording, or } \\
\text { both) }\end{array}$ & $45.45 \%$ \\
\hline Other, please specify: & $0 \%$ \\
\hline
\end{tabular}

\subsection{User evaluation}

End-users were asked to select the $A D$ aspects they value most from a pre-established list (ADLAB PRO, 2017) of ten items (possible multiple answers). The items most favoured (Table 7) include a sentence structure that is clear and easy to follow and an AD that helps with understanding and enjoying the product (66.66\%). Although the phrasing of this item can be viewed as rather subjective (see Table 7), what is interesting to notice is the importance 
Mendoza, N., \& Matamala, A. (2019). Skills and competences of audio describers in Spain. Linguistica Antverpiensia, New Series: Themes in Translation Studies, 18, 144-165.

attached not only to understanding but also to enjoying the content. Other textual/linguistic aspects are also prioritized, such as the selection and organization of information (58.33\%), the narrative of $A D(50 \%)$ or the vocabulary used $(41.66 \%)$. In turn, the appreciation of technical aspects varies between the aspects that audio describers cannot control $(58.33 \%)$ and those they can control (25\%). A diversification in line with ADLAB PRO results is observed, showing that a good AD is a "blend of several aspects that need to co-occur" (ADLAB PRO, 2017, p. 27).

Table 7: User evaluation of AD aspects

\begin{tabular}{|l|l|}
\hline AD aspects & $\begin{array}{l}\text { Number of } \\
\text { users and \% }\end{array}$ \\
\hline Sentence structure of the AD (clear and easy to follow) & $8(66.66 \%)$ \\
\hline AD that really helps end-users to understand and enjoy the product & $8(66.66 \%)$ \\
\hline Selection and organization of the information & $7(58.33 \%)$ \\
\hline Language and style of the AD that are suited to the audience and to the product & 7 (58.33\%) \\
\hline $\begin{array}{l}\text { Technical aspects of the AD that the audio describer cannot control (e.g., sound } \\
\text { quality, mix of the AD with original sound) }\end{array}$ & $7(58.33 \%)$ \\
\hline Narrative of the AD (the description helps you follow the story) & $6(50 \%)$ \\
\hline Engaging AD that gives the listener an emotional experience & $6(50 \%)$ \\
\hline Vocabulary of the AD (vivid, imaginative, clear, adequate) & $5(41.66 \%)$ \\
\hline Grammatically correct language & $5(41.66 \%)$ \\
\hline $\begin{array}{l}\text { Technical aspects of the AD that the audio describer can control (e.g., AD } \\
\text { timing, vocal skills) }\end{array}$ & $3(25 \%)$ \\
\hline
\end{tabular}

Regarding user satisfaction with existing AD quality, 75\% claimed to be "satisfied" and 8.33\% respectively feel "very satisfied", "neither satisfied nor dissatisfied", and "dissatisfied", which shows a significant level of general appreciation. However, the users do not always value aspects that audio describers find "important" or "extremely important", as will be discussed in more detail in section 4.5.

The elements users dislike the most (Tables 8-11 in Annex I) are the lack of synchronization of the $A D$ with the dialogue and sound effects or with the images (83.33\%); this is a critical aspect also selected by $75 \%$ of the users under the list of technical aspects ("AD timing"). ADs not making the product easy to follow are next (66.66\%), followed by significant omissions and $A D$ overlapping with dialogue or critical sound effects. The same percentage of users also select "failure to provide you with a way of understanding what is described", a textual aspect much related to the previous ones, and "the mix of the AD with the original sound". On the contrary, users seem not to be perturbed by ADs that include too much information or "excess 
Mendoza, N., \& Matamala, A. (2019). Skills and competences of audio describers in Spain. Linguistica Antverpiensia, New Series: Themes in Translation Studies, 18, 144-165.

of details". When asked about the things they dislike the most in an AD, no users selected the inability to use literary devices or the vocal skills of the audio describers (ability to deliver $A D$ clearly and engagingly).

\subsection{End-users' vs audio describers' insights}

The results from the professionals summarized in Tables 2 and 3 were compared to the results from users in Table 7 and in Annex I (Tables 8-11). Although different phrasings and scales were used, which is a methodological limitation, a general comparison is interesting as it may hint at some trends.

Both audio describers and end-users consider it important to provide the listener with a way of "understanding" what is described. $66.66 \%$ of the users (Table 7) report "understanding" is one of the aspects they appreciate the most and the same percentage responded that this is the aspect they dislike the most (Table 10) when it is not achieved. Audio describers also consider it to be an important skill for professionals to acquire (4.27/5).

However, other aspects that are highly relevant to audio describers do not seem to be as important to end-users. Audio describers give the maximum score (5/5) to the item "select significant visual information", whereas only $58.33 \%$ of users report this aspect as an element they appreciate the most in an AD. Similarly, while professionals find the use of language suited to the product an important skill (4.9/5), the percentage of users reporting this aspect as most appreciated does not go beyond $58.33 \%$. This trend is repeated in other items of a linguistic nature, such as use of ambiguous language. This is probably due to the diverging approaches towards AD: while audio describers are aware of the importance of visual content selection and linguistic choices to deliver a quality $A D$ that follows current standards, endusers are probably interested in $A D$ as a global service in which these specific challenges go unnoticed.

Despite the shared focus on making content understandable, the data show a number of discrepancies between users' and professionals' priorities. The reasons for this may be methodological: the phrasing of the questions was different for both profiles. Moreover, the specific personal and professional backgrounds of the respondents may influence their priorities regarding $A D$, and therefore also have an impact on the results. Since most of the audio describers have a language-related educational background, it could be argued that they may rate textual/linguistic aspects as more important than end-users.

\section{Interviewees' insights}

The lecturers were asked whether they cover each of the skills (Tables 12-15) identified in the questionnaire in their $A D$ courses and, if not, they were asked to indicate why.

Regarding soft skills, $3 / 11$ items (27.27\%) are taught in all the courses (Table 12 ): "be assertive and fight for the quality of AD provision" (4.72/5 importance by audio describers in the questionnaire), "organize work efficiently" (4.54/5) and "solve problems" (4.18/5). 
Mendoza, N., \& Matamala, A. (2019). Skills and competences of audio describers in Spain. Linguistica Antverpiensia, New Series: Themes in Translation Studies, 18, 144-165.

Table 12: Interviewees' insights into soft skills

\begin{tabular}{|c|c|c|c|c|c|c|}
\hline Soft skills & Yes & $\begin{array}{l}\text { No, no } \\
\text { time }\end{array}$ & $\begin{array}{l}\text { No, no } \\
\text { need }\end{array}$ & $\begin{array}{l}\text { No, to } \\
\text { be } \\
\text { acquired } \\
\text { before }\end{array}$ & $\begin{array}{l}\text { No, in } \\
\text { another } \\
\text { subject }\end{array}$ & $\begin{array}{l}\text { No, } \\
\text { other } \\
\text { reasons }\end{array}$ \\
\hline $\begin{array}{l}\text { Be assertive and fight for the quality } \\
\text { of } A D \text { provision }\end{array}$ & $100 \%$ & & & & & \\
\hline $\begin{array}{l}\text { Actively seek, evaluate and, if } \\
\text { appropriate, incorporate feedback }\end{array}$ & $80 \%$ & & & & $20 \%$ & \\
\hline Organize work efficiently & $100 \%$ & & & & & \\
\hline $\begin{array}{l}\text { Have good communicative and } \\
\text { interpersonal skills }\end{array}$ & $60 \%$ & & & $40 \%$ & & \\
\hline Solve problems & $100 \%$ & & & & & \\
\hline Work in a team with blind patrons & $60 \%$ & $20 \%$ & & & & $20 \%$ \\
\hline Know when to call for expert help & $80 \%$ & & & & & $20 \%$ \\
\hline Cope with time pressure & $60 \%$ & & $20 \%$ & & & $20 \%$ \\
\hline Work in a team with colleagues & $80 \%$ & & $20 \%$ & & & \\
\hline Improvise & $40 \%$ & & $40 \%$ & & & $20 \%$ \\
\hline Write quickly to a deadline & $20 \%$ & & $40 \%$ & $20 \%$ & & $20 \%$ \\
\hline
\end{tabular}

From the skills not unanimously covered, $40 \%$ of the lecturers consider that "good communicative and interpersonal skills" should be acquired before starting the MA. Taking into consideration that this skill was assigned an importance value of $4.27 / 5$, establishing it as a prerequisite in the admission process may be critical. In $40 \%$ of the courses students are not trained in working in a team with blind patrons, despite the importance attributed to it in the questionnaire (4.18/5), either because of time constraints or because students are encouraged to train this skill on their own. One interviewee claimed this self-learning approach to be beneficial for the class. Moreover, "cope with time pressure" (3.9/5) brought different answers: $60 \%$ enhance this skill in class, whereas $20 \%$ do not find it necessary. The remaining $20 \%$ insist on its importance, but do not provide training for this. Answers also vary regarding "improvise" $(2.45 / 5)$ as a necessary skill: $40 \%$ cover it, but $40 \%$ do not find it necessary and $20 \%$ acknowledge that students are implicitly trained in this when problems are discussed in class. A possible reason for not obtaining a unanimous answer might be that $A D$ courses usually deal with recorded $A D$ rather than live $A D$, where mastering the skill of improvisation is fundamental. Finally, the skill phrased as "write quickly to a deadline" generated some confusion among interviewees, resulting in diversified replies: $20 \%$ cover this, $40 \%$ do not find it necessary, $20 \%$ think it should be acquired prior to the MA and $20 \%$ doubt this should be a skill in itself. It is worth highlighting that the importance attached to this skill in the questionnaire was $2.45 / 5$. 
Mendoza, N., \& Matamala, A. (2019). Skills and competences of audio describers in Spain. Linguistica Antverpiensia, New Series: Themes in Translation Studies, 18, 144-165.

As for the items related to theoretical knowledge (Table 13), 55.55\% of them are covered in all the courses in Spain: "target group" (4.81/5 importance by audio describers), "AD principles, guidelines, standards" (4.36/5), "media accessibility" (4.27/5), "scriptwriting" $(4.09 / 5)$ and "AD history, status, applicable scenarios" (3.45/5). For the skills not being covered by all, there are some trends: $40 \%$ give attention to "language and linguistics" (4.54/5) and $40 \%$ to "audiovisual texts and multimodality" $(4 / 5)$ in other courses in the MAs. Eighty per cent find students should have "world knowledge" (4.36/5) before starting the MA. Besides, $20 \%$ think "Translation Studies and AVT" (3.27/5) should be learnt before the MA and 20\% shift this type of knowledge to another subject in the MA.

Table 13: Interviewees' insights into theoretical knowledge

\begin{tabular}{|c|c|c|c|c|c|c|}
\hline Theoretical knowledge & Yes & $\begin{array}{l}\text { No, no } \\
\text { time }\end{array}$ & $\begin{array}{l}\text { No, no } \\
\text { need }\end{array}$ & $\begin{array}{l}\text { No, to } \\
\text { be } \\
\text { acquired } \\
\text { before }\end{array}$ & $\begin{array}{l}\text { No, in } \\
\text { another } \\
\text { subject }\end{array}$ & $\begin{array}{l}\text { No, } \\
\text { other } \\
\text { reasons }\end{array}$ \\
\hline Target group & $100 \%$ & & & & & \\
\hline Language and linguistics & $60 \%$ & & & & $40 \%$ & \\
\hline World knowledge & $20 \%$ & & & & $80 \%$ & \\
\hline AD principles, guidelines, standards & $100 \%$ & & & & & \\
\hline Media accessibility & $100 \%$ & & & & & \\
\hline Scriptwriting & $100 \%$ & & & & & \\
\hline Audiovisual texts and multimodality & $60 \%$ & & & & $40 \%$ & \\
\hline $\begin{array}{l}\text { AD history, status, applicable } \\
\text { scenarios }\end{array}$ & $100 \%$ & & & & & \\
\hline Translation studies and AVT & $60 \%$ & & & $20 \%$ & $20 \%$ & \\
\hline
\end{tabular}

Technical skills (Table 14) provide a more diverse picture. Only one item, "technology of AD provision", (4/5 importance by audio describers), is trained across all courses. "Use of AD software" (4/5 importance) is not considered necessary by $20 \%$, whereas $20 \%$ cover it in a different section of the MA. Twenty per cent prioritize other skills over "AD voicing" (3.54/5), due to time constraints. Regarding "mixing of AD with original sound" (3.54), 40\% do not have enough time to include it in the course and $20 \%$ do not find it a necessary skill. A similar scenario applies to "AD recording" (3.45/5): 40\% lack time to train this and $20 \%$ do not include it in the course because of unknown reasons. These findings seem to be in line with job opportunities and current practices in Spain, where the voicing of recorded ADs is sometimes performed by voice talents and the mixing is performed by technicians. This may explain why $A D$ recording, mixing and voicing are not considered to be of maximum importance by audio describers and, similarly, are not thoroughly explored in courses. In relation to AD software, one of the lecturers proposes a more holistic approach: learners could focus on key tasks common to different software types (time-coding, for instance) rather than on specific 
Mendoza, N., \& Matamala, A. (2019). Skills and competences of audio describers in Spain. Linguistica Antverpiensia, New Series: Themes in Translation Studies, 18, 144-165.

software. Based on the variety of the results issued, future studies focusing on technical skills would be helpful.

Table 14: Interviewees' insights into technical skills

\begin{tabular}{|l|l|l|l|l|l|l|}
\hline Technical skills & Yes & $\begin{array}{l}\text { No, no } \\
\text { time }\end{array}$ & $\begin{array}{l}\text { No, no } \\
\text { need }\end{array}$ & $\begin{array}{l}\text { No, to } \\
\text { be } \\
\text { acquired } \\
\text { before }\end{array}$ & $\begin{array}{l}\text { No, in } \\
\text { another } \\
\text { subject }\end{array}$ & $\begin{array}{l}\text { No, } \\
\text { other } \\
\text { reasons }\end{array}$ \\
\hline AD scriptwriting and textual editing & $80 \%$ & & & & $20 \%$ & \\
\hline Use of AD software & $60 \%$ & & $20 \%$ & & $20 \%$ & \\
\hline Technology of AD provision & $100 \%$ & & & & & \\
\hline AD voicing & $80 \%$ & $20 \%$ & & & & \\
\hline Mixing AD with original sound & $40 \%$ & $40 \%$ & $20 \%$ & & & \\
\hline AD recording & $40 \%$ & $40 \%$ & & & & $20 \%$ \\
\hline
\end{tabular}

All AD courses, without exception, cover $70 \%$ of the textual/linguistic items (Table 15), in particular: "select significant visual information" (5/5 importance by audio describers), "use language that is suited to the product" (4.9/5), "express meaning succinctly" (4.90/5), "use non-ambiguous language" (4.81/5), "use language that is suited to the audience" (4.72/5), "provide the listener with a way of 'seeing what is being described' (4.54/5), and "use language that sparks the imagination" (4.09/5). Yet $60 \%$ find that students should "possess an excellent command of the mother tongue" (5/5) before starting the MA. Considering the maximum importance given to this skill, rigorous admission requirements are paramount.

Furthermore, "provide the listener with a way of "understanding'" $(4.27 / 5)$ is practised in $80 \%$ of the courses. A lecturer (20\%) highlighted that audio describers should not be patronizing and picked the "no, no need" box. The discrepancy could be down to the particular interpretation of the lecturer for this item. In relation to "compile audio introductions" (3.27/5), limited time can be invested in its practice, according to $40 \%$, which is in line with the lower prioritization given in the questionnaire.

Table 15: Interviewees' insights into textual/linguistic skills

\begin{tabular}{|l|l|l|l|l|l|l|}
\hline Textual/linguistic skills & Yes & $\begin{array}{l}\text { No, no } \\
\text { time }\end{array}$ & $\begin{array}{l}\text { No, no } \\
\text { need }\end{array}$ & $\begin{array}{l}\text { No, to } \\
\text { be } \\
\text { acquired } \\
\text { before }\end{array}$ & $\begin{array}{l}\text { No, in } \\
\text { another } \\
\text { subject }\end{array}$ & $\begin{array}{l}\text { No, } \\
\text { other } \\
\text { reasons }\end{array}$ \\
\hline $\begin{array}{l}\text { Possess an excellent command of } \\
\text { mother tongue }\end{array}$ & $40 \%$ & & & $60 \%$ & & \\
\hline Select significant visual information & $100 \%$ & & & & & \\
\hline
\end{tabular}


Mendoza, N., \& Matamala, A. (2019). Skills and competences of audio describers in Spain. Linguistica Antverpiensia, New Series: Themes in Translation Studies, 18, 144-165.

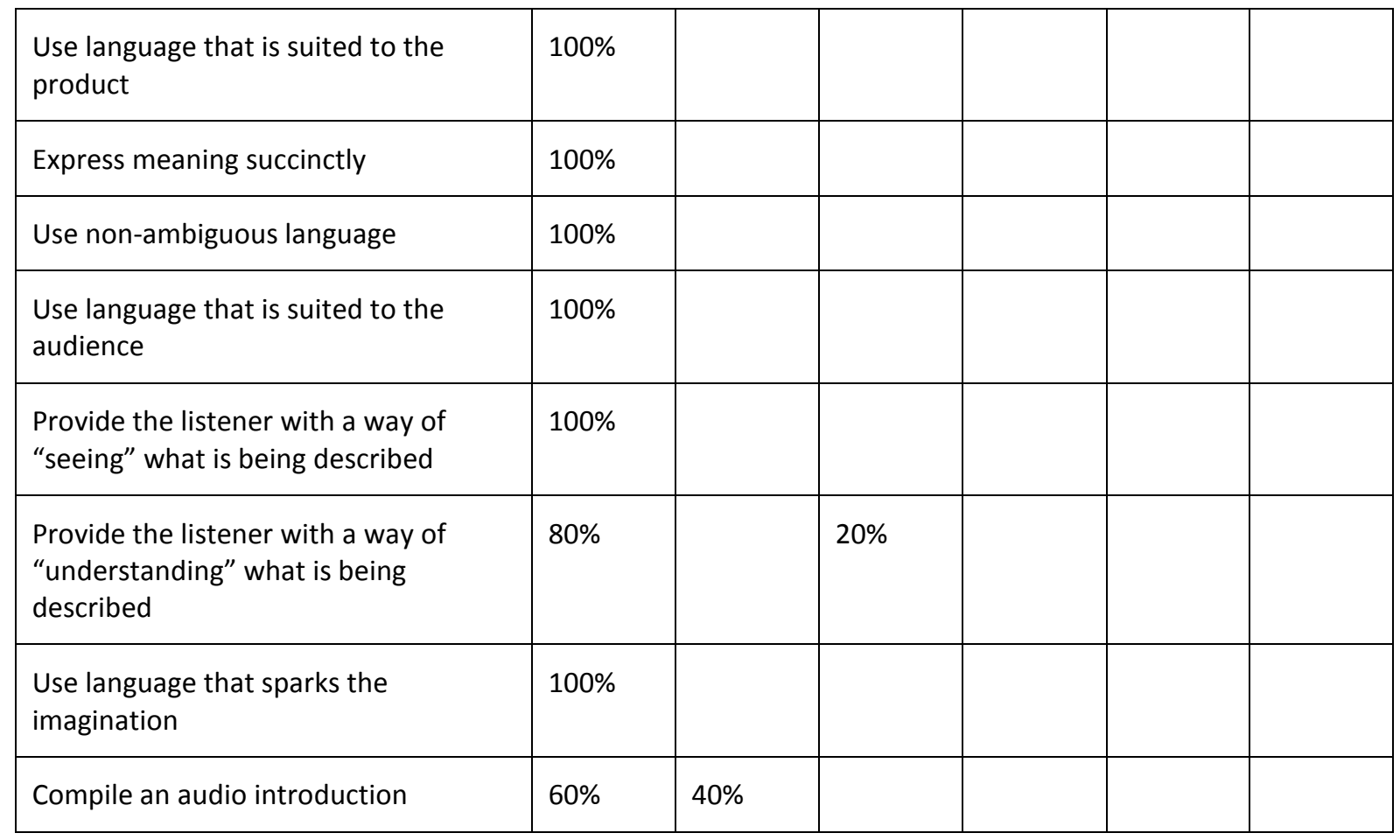

All in all, the skills identified by audio describers as most important are also included in the AD courses. Even those that are least prioritized are also generally practised. The differences found are mainly related to these aspects: skills that students should already have (i.e., prerequisites), that are explained but not practised thoroughly due to time constraints, and skills for which training is received in other courses in the same MA. Finally, textual/linguistic skills continue to emerge as the most important, according to audio describers and also as the most practised in the AD courses. In turn, technical skills generate more divergences and are therefore an advisable object of future study.

\section{Conclusions}

The acquisition of skills is inherent in the students' learning process. In particular, employability has been a key issue since the emergence of the European Higher Education Area. In fact,

with labour markets increasingly relying on higher skill levels and transversal competences, higher education should equip students with the advanced knowledge, skills and competences they need throughout their professional lives (European Higher Education Area, 2016).

Successfully training $A D$ professionals is a responsibility shared by governments, academic institutions, employers and students themselves. First, we aimed to research the skills Spanish audio describers need to acquire by analysing the data derived from a questionnaire created and administered by ADLAB PRO. Secondly, we conducted interviews with lecturers of $A D$ courses in five Spanish MAs in order to verify whether the skills identified in the questionnaire are covered in those AD courses.

The Spanish data from the questionnaire showed that audio describers attach special importance to textual/linguistic aspects. This is consistent with the EMT's perspective, for 
Mendoza, N., \& Matamala, A. (2019). Skills and competences of audio describers in Spain. Linguistica Antverpiensia, New Series: Themes in Translation Studies, 18, 144-165.

which the linguistic skills are "the driving force" (European Commission, 2017, p. 6). Similarly, these skills are thoroughly developed in the AD courses under analysis, or are prerequisites in some cases.

Concerning the most practised AD-related "stages", the focus on textual/linguistic aspects was unanimous. Lengthier or more specialized training programmes that focus on different $A D$ typologies and technical skills could better account for different working situations.

Skills identified in the questionnaire were compared to those covered in the AD courses. Concerning soft skills, many are not included for various reasons. In some cases, lecturers thought that a specific skill should be acquired before the MA, for example, having good communicative and interpersonal skills. Time constraints also played a part, for instance, in not including the participation of blind patrons in the actual class. Some skills, such as the ability to improvise or to cope with time pressure, were in some cases not covered because they were not found to be necessary.

Theoretical knowledge is practised either in the AD course or in another course of the MA. When this is not the case, lecturers consider them necessary before enrolling on the programme.

Technical skills displayed the most divergent data. They are not covered in class to a large extent, the reasons being the lack of time or the fact that they are not considered necessary. Even though these reasons might be in line with the professional profile demanded by the market in Spain, keeping up to date with future professional trends would be advisable so that students are ready for a global market which may request that professionals master a wider diversification of $A D$ tasks. Finally, textual/linguistic skills appeared to be of greater significance, some of them, such as a good command of the mother tongue, being considered prerequisites.

Overall, this study has provided insights into the skills of audio describers in Spain. The results do not only allow for a better understanding of current training practices, but they do provide food for thought for future curriculum designs. Further work on aspects such as teaching methodologies or assessment would undoubtedly contribute towards obtaining a more detailed picture of the current $A D$ training scenario and provide hints for future training in the field.

\section{References}

ADLAB PRO. (n.d.). Audio description: A laboratory for the development of a new professional profile. Retrieved from https://www.adlabpro.eu/

ADLAB PRO. (2017). Audio description professional: Profile definition. Retrieved from https://www.adlabpro.eu/wp-content/uploads/2018/04/IO2-REPORT-Final.pdf

Agencia Nacional de Evaluación de la Calidad y Acreditación. (2013). Guía de apoyo para la redacción, puesta en práctica y evaluación de los resultados de aprendizaje. Retrieved from http://portal.uned.es/pls/portal/docs/PAGE/UNED_MAIN/LAUNIVERSIDAD/VICERRECTORADO S/CALIDAD_E_INTERNACIONALIZACION/INNOVACION_DOCENTE/IUED/MATERIALES\%2ODIDAC TICOS/WEB_MADI_MANUAL_DOCENTIA_UNED_APROBADO_ANECA_09_04_20_0.PDF 
Mendoza, N., \& Matamala, A. (2019). Skills and competences of audio describers in Spain. Linguistica Antverpiensia, New Series: Themes in Translation Studies, 18, 144-165.

Álvarez de Morales Mercado, C. (2017). Didáctica de la traducción accesible en el turismo y su aplicación en enseñanzas de posgrado. Revista digital de investigación en docencia universitaria, 11(2), 223-236.

Cambeiro Andrade, E., \& Quereda Herrera, M. (2007). La audiodescripción como herramienta didáctica para el aprendizaje del proceso de traducción. In C. Jiménez Hurtado (Ed.), Traducción y accesibilidad: subtitulación para sordos y audiodescripción para ciegos: nuevas modalidades de Traducción Audiovisual (pp. 273-287). Bern: Peter Lang.

Díaz Cintas, J. (2006). Competencias profesionales del subtitulador y el audiodescriptor. Retrieved from http://www.cesya.es/sites/default/files/documentos/informe_formacion.pdf

European Commission. (n.d.). The European Qualifications Framework for Lifelong Learning. Retrieved from https://ec.europa.eu/ploteus/sites/eac-eqf/files/leaflet_en.pdf

European Commission. (2015). ECTS' Users Guide. Retrieved from https://europass.cedefop.europa. eu/sites/default/files/ects-users-guide_en.pdf

European Commission. (2017). European Master's in Translation. Retrieved from https://ec.europa. eu/info/sites/info/files/emt_competence_fwk_2017_en_web.pdf

European Higher Education Area. (2016). Employability in the Bologna Process. Retrieved from http:// www.ehea.info/cid102533/employability-historical-review.html

Kennedy, D. (2007). Writing and using learning outcomes: A practical guide. Retrieved from https:// www.cmepius.si/wp-content/uploads/2015/06/A-Learning-Outcomes-Book-D-Kennedy.pdf

Martínez Sierra, J. J. (Ed.). (2012). Reflexiones sobre la traducción audiovisual: Tres espectros, tres momentos. Valencia: University of Valencia.

Marzà Ibáñez, A. (2010). Evaluation criteria and film narrative: A frame to teaching relevance in audio description. Perspectives: Studies in Translatology, 18(3), 143-153.

Matamala, A. (2006). La accesibilidad en los medios: Aspectos lingüísticos y retos de formación. In R. Pérez-Amat \& Á. Pérez-Ugena (Eds.), Sociedad, integración y televisión en España (pp. 293-306). Madrid: Laberinto.

Matamala, A., \& Orero, P. (2007). Designing a course on audio description: Main competences of the future professional. Linguistica Antverpiensia, New Series - Themes in Translation Studies, 6, 329-344.

Mendoza, N., \& Matamala, A. (2019). Panorama de la enseñanza de la audiodescripción en España: Resultados de un cuestionario. MonTI: Monografías de Traducción e Interpretación, 11, 155185.

Ministerio de Educación, Cultura y Deporte. (n.d.). Registro de Universidades, Centros y Títulos (RUCT). Retrieved from https://www.educacion.gob.es/ruct/home

Remael, A., \& Vercauteren, G. (2007). Audio describing the exposition phase of films: Teaching students what to choose. TRANS: Revista de Traductología, 11, 73-94.

Reyes, M. P. E. (2007). La introducción de la audiodescripción como herramienta didáctica en el aula de traducción (Unpublished master's thesis). University of Granada, Granada.

Sanz-Moreno, R. (2018). Perfil y competencias del audiodescriptor en España. HIKMA: Revista de Traducción, 17, 119-143.

Sarzoza Herrera, S. (2007). Enfoques de aprendizaje y formación en competencias en educación superior (Unpublished doctoral dissertation). University of Granada, Granada.

Snyder, J. (2008). Audio description: The visual made verbal. In J. Díaz Cintas (Ed.), The didactics of audiovisual translation (pp. 191-198). Amsterdam: John Benjamins.

Snyder, J. (2014). The visual made verbal: A comprehensive training manual and guide to the History and Applications of Audio Description. Indianapolis, IN: Dog Ear.

UNESCO-IBE. (n.d.). Key competences/competencies or skills. Retrieved from http://www.ibe.unesco. org/en/glossary-curriculum-terminology/k/key-competencescompetencies-or-skills 
Mendoza, N., \& Matamala, A. (2019). Skills and competences of audio describers in Spain. Linguistica Antverpiensia, New Series: Themes in Translation Studies, 18, 144-165.

\section{Annexes}

\section{Annex I}

Table 8: AD aspects disliked by Spanish end-users: quality of information

\begin{tabular}{|c|c|}
\hline AD aspects & $\begin{array}{l}\text { Number of users } \\
\text { and \% }\end{array}$ \\
\hline The AD is not well synchronized with the dialogue and sound effects or with the images & $10(83.33 \%)$ \\
\hline The AD does not make the product easy to follow & $8(66.66 \%)$ \\
\hline $\begin{array}{l}\text { The AD includes significant omissions (e.g. unexplained noises or unidentified } \\
\text { characters) }\end{array}$ & $8(66.66 \%)$ \\
\hline The audio describer talks over the dialogue or critical sound effects & $8(66.66 \%)$ \\
\hline $\begin{array}{l}\text { The audio describer gives their own opinion and prevents you from drawing your own } \\
\text { conclusions }\end{array}$ & 7 (58.33\%) \\
\hline $\begin{array}{l}\text { The AD is not coherent (i.e., does not make comprehensible links between visual } \\
\text { images, between images and sound and between images and dialogue) }\end{array}$ & $6(50 \%)$ \\
\hline The AD includes too little information & $6(50 \%)$ \\
\hline The AD does not give you independence & $5(41.66 \%)$ \\
\hline The audio describer does not know what to say, how to say it, where to say it & $5(41.66 \%)$ \\
\hline $\begin{array}{l}\text { The AD does not convey the world of the product (by product we mean, e.g., play, film, } \\
\text { episode of a TV series or TV programme, work of art such as painting or artefact, etc.) }\end{array}$ & $3(25 \%)$ \\
\hline The AD does not make the product more enjoyable & $3(25 \%)$ \\
\hline The AD includes too much information & $1(8.33 \%)$ \\
\hline
\end{tabular}

Table 9: AD aspects disliked by Spanish end-users: language and style

\begin{tabular}{|l|l|}
\hline AD language and style according to the end-users & $\begin{array}{l}\text { Number of users } \\
\text { and } \%\end{array}$ \\
\hline Too many repetitions & $7(58.33 \%)$ \\
\hline Lack of comprehensible vocabulary & $6(50 \%)$ \\
\hline Lack of comprehensible sentence structure & $6(50 \%)$ \\
\hline The description is not engaging & $5(41.66 \%)$ \\
\hline Ambiguous language & $4(33.33 \%)$ \\
\hline Language not suited to the product & $4(33.33 \%)$ \\
\hline
\end{tabular}


Mendoza, N., \& Matamala, A. (2019). Skills and competences of audio describers in Spain. Linguistica Antverpiensia, New Series: Themes in Translation Studies, 18, 144-165.

\begin{tabular}{|l|l|}
\hline Lack of grammatically correct language & $3(25 \%)$ \\
\hline Lack of specialized language and terminology & $3(25 \%)$ \\
\hline Lack of evocative vocabulary & $2(16.66 \%)$ \\
\hline Language not suited to the audience & $2(16.66 \%)$ \\
\hline Inaccurate use of words & $2(16.66 \%)$ \\
\hline
\end{tabular}

Table 10: AD aspects disliked by Spanish end-users: textual aspects

\begin{tabular}{|l|l|}
\hline AD textual aspects and the end-users & $\begin{array}{l}\text { Number of users } \\
\text { and } \%\end{array}$ \\
\hline Failure to provide you with a way of understanding what is described & $8(66.66 \%)$ \\
\hline Lack of details & $7(58.33 \%)$ \\
\hline Lack of effective narrative (description fails to tell a story and engage the listener) & $6(50 \%)$ \\
\hline Failure to provide you with a way of "seeing" what is described & $6(50 \%)$ \\
\hline Lack of background and contextual information & $5(41.66 \%)$ \\
\hline Failure to provide an emotional experience & $4(33.33 \%)$ \\
\hline Phraseology and wording & $3(25 \%)$ \\
\hline Lack of audio introductions & $3(25 \%)$ \\
\hline General organization of the AD text & $2(16.66 \%)$ \\
\hline $\begin{array}{l}\text { Inability to use imagery that appeals to senses other than vision (e.g., touch, taste, } \\
\text { smell) }\end{array}$ & $2(16.66 \%)$ \\
\hline Excess of details & $1(8.33 \%)$ \\
\hline Selection of visual information & $1(8.33 \%)$ \\
\hline Inability to use literary devices (e.g., simile or metaphor) & $0(0 \%)$ \\
\hline
\end{tabular}

Table 11: AD aspects disliked by Spanish end-users: technical aspects

\begin{tabular}{|l|l|}
\hline Technical aspects of AD according to the end-users & $\begin{array}{l}\text { Number of users } \\
\text { and } \%\end{array}$ \\
\hline AD timing & $9(75 \%)$ \\
\hline The mix of the AD with original sound & $8(66.66 \%)$ \\
\hline Technical sound editing (e.g., cutting out repetitions so the recording flows smoothly) & $4(33.33 \%)$ \\
\hline
\end{tabular}


Mendoza, N., \& Matamala, A. (2019). Skills and competences of audio describers in Spain. Linguistica Antverpiensia, New Series: Themes in Translation Studies, 18, 144-165.

Vocal skills of the audio describer (ability to deliver AD clearly and engagingly)

$0(0 \%)$

1 This work has been supported by ADLAB PRO (Audio Description: A Laboratory for the Development of a New Professional Profile), financed by the European Union under the Erasmus+ Programme, Key Action 2 - Strategic Partnerships, Project number: 2016-1-IT02-KA203-024311. The first author is currently affiliated to the PhD programme in Translation and Intercultural Studies of the Universitat Autònoma de Barcelona. The second author is a member of TransMedia Catalonia, a research group funded by Generalitat de Catalunya (2017SGR113). The information and views set out in this article are those of the authors and do not necessarily reflect the official opinion of the European Union. Neither the European Union institutions and bodies nor any person acting on their behalf may be held responsible for the use which may be made of the information contained in this article.

2 The original English version of the questionnaire is available at http://www.adlabpro.eu/wpcontent/uploads/2017/12/io2-questionnaire-final-en.pdf.

3 Currently, in Spain, all PhD candidates should have a previous MA in order to access PhD programmes. However, the sequencing of undergraduate and postgraduate studies was different in pre-Bologna times. This explains why a scenario of $\mathrm{PhDs} / \mathrm{PhD}$ candidates without an MA is possible in Spain. 